\title{
“GGE BIPLOT” ASSESSMENT OF PHENOTYPIC STABILITY OF_SPRING BARLEY VARIETIES
}

Solonechnyi P. M., Kozachenko M. R., Vasko N. I., Naumov O. G., Solonechna O. V., Vazhenina O. E.

Plant Production Institute nd. a V. Ya. Yuriev of NAAS, Ukraine

Bondareva O. B.

Donetsk Experiment Station of NAAS, Ukraine

Kovalenko A. L.

Research Station of Bast Crops of the Institute of Agriculture of Northern-East NAAS, Ukraine

The article presents GGE biplot analysis of results of environmental trials in 17 varieties of spring barley bred at the Plant Production Institute nd. a V.Ya. Yuriev of NAAS. The study results discriminate genotypes with stable realization of their genetic potential in a number of environments as well as genotypes combining a high level of a trait with its stable expression. The varieties Kozvan, Perl, Agrariy and Kosar were chosen as valuable source material for spring barley breeding. We think that GGE biplot can be a comprehensive alternative to the most conventional methods of assessment of adaptive features in genotypes.

Key words: GGE Biplot, spring barley, environmental variety trial, stabiltity, adaptability, performance, genotype

Introduction. Barley (Hordeum vulgare L.) is a strategic export-oriented agricultural plant in Ukraine. Increase in gross output of barley grain is impossible without implementation of high-yielding barley varieties that are resistant to biotic and abiotic factors.

Analysis of publications, pose the problem. Environmental variety trials are an important tool for selection of genotypes with specific (narrow) or wide adaptation to a certain environment or to a range of environments, which enables predicting yield capacity of genotypes under these conditions and ultimately increases farmers' labor efficiency [1,2]. Nevertheless, capabilities of environmental trials are not always used to the full: usually yield capacity of genotypes is only analyzed, but information on other traits remains unstudied [3].

The observed phenotypic variance $(\mathrm{P})$ of traits consists of environment variance $(\mathrm{E})$, genotype variance $(\mathrm{G})$ and genotype $\times$ environment interaction $(\mathrm{GE}): \mathrm{P}=\mathrm{G}+\mathrm{GE}+\mathrm{E}$ or $\mathrm{P}-\mathrm{E}=$ $\mathrm{G}+\mathrm{GE}$ [4]. W. Yan [5] points out that $\mathrm{E}$ effect forms the major part of the total phenotype variability, and contributions of G and GE are generally small. However, G and GE effects must be taken into account in the process of selection of high-yielding genotypes.

The term «GGE» emphasizes understanding that $\mathrm{G}$ and GE are two sources of variation that are pertinent to genotype assessment and must be considered simultaneously, when genotype $\times$ environment interactions are investigated.

With time, GGE biplot analysis has turned into a complex analysis system, as a result of which the majority of environmental trial datum patterns can be displayed graphically [6-9].

The aim and tasks of the study. The study purpose was evaluation of adaptive features of spring barley varieties in terms of performance and its elements using GGE biplot and discrimination of valuable source material for breeding of this plant.

Material and methods. The source material was 17 varieties of spring barley bred at the Plant Production Institute nd. a V. Ya. Yuriev of NAAS. To determine their adaptive potential, in 2013 environmental trials were conducted in three locations with different soilclimatic conditions: Plant Production Institute nd. a V. Ya. Yuriev of NAAS (Eastern Forest-

(C) Solonechnyi P. M., Kozachenko M. R., Vasko N. I., Naumov O. G., Solonechna O. V., Vazhenina O. E., Bondareva O. B., Kovalenko A. L. 2015.

ISSN 0582-5075. Plant Breeding and Seed Production. 2015. Issue 107. 
Steppe) - environment E1, Donetsk Experiment Station of NAAS (Southern Steppe) - environment E2 and Research Station of Bast Crops of the Institute of Agriculture of NorthernEast NAAS (North-Eastern Forest-Steppe) - environment E3. In addition to yield capacity, variability of performance elements was evaluated: grain weight per plant, productive tillering, grain number per spike and 1000-grain weight. The environmental trial data were analyzed by GGE biplot.

GGE biplot graphs were constructed using the first two principal components PC1 и PC2 derived from subjecting the data to singular-value decomposition. Only two principal components (PC1 and PC2) are retained in the model because such a model tends to be the best model for visualizing interaction between each genotype and test environments.

All GGE biplots were constructed using Genstat 17.

Results and discussion. The results of the environmental trials showed a significant differentiation of the studied varieties in terms of plant performance and its elements (table 1).

Table 1

Performance and its Elements in the Spring Barley Varieties in the Environmental Trials, 2013.

\begin{tabular}{|c|l|c|c|c|c|}
\hline $\begin{array}{c}\text { Variety } \\
\text { code }\end{array}$ & Variety & $\begin{array}{c}\text { Productive } \\
\text { tillering, pcs. }\end{array}$ & $\begin{array}{c}\text { Grain number } \\
\text { per spike, pcs. }\end{array}$ & $\begin{array}{c}\text { 1000-grain } \\
\text { weight, g }\end{array}$ & $\begin{array}{c}\text { Performance, } \\
\text { g }\end{array}$ \\
\hline G1 & Agrariy & 2,4 & 22,4 & 42,5 & 2,35 \\
\hline G2 & Alegro & 2,0 & 20,4 & 48,0 & 1,80 \\
\hline G3 & Vektor & 2,0 & 20,5 & 50,5 & 2,10 \\
\hline G4 & Vzirets & 1,8 & 20,9 & 44,7 & 1,70 \\
\hline G5 & Vyklyk & 1,8 & 19,5 & 46,0 & 1,83 \\
\hline G6 & Vitrazh & 2,2 & 21,6 & 45,5 & 2,27 \\
\hline G7 & Dyvogliad & 1,8 & 21,8 & 44,5 & 1,73 \\
\hline G8 & Dokaz & 2,0 & 18,2 & 47,0 & 1,87 \\
\hline G9 & Etyket & 2,2 & 19,2 & 47,5 & 2,27 \\
\hline G10 & Zdobutok & 1,7 & 21,2 & 48,5 & 2,03 \\
\hline G11 & Inkliuziv & 1,5 & 20,0 & 47,3 & 1,80 \\
\hline G12 & Kozvan & 2,8 & 20,9 & 41,7 & 2,37 \\
\hline G13 & Kosar & 2,4 & 22,5 & 47,5 & 2,23 \\
\hline G14 & Modern & 2,1 & 21,6 & 44,3 & 1,87 \\
\hline G15 & Parnas & 1,5 & 18,1 & 44,2 & 1,43 \\
\hline G16 & Perl & 2,2 & 19,1 & 49,5 & 2,33 \\
\hline G17 & Shchedriy & 1,7 & 21,7 & 48,3 & 1,63 \\
\hline LSD 05 & 0,36 & 1,13 & 1,20 & 0,18 & \\
\hline
\end{tabular}

Analysis of variance demonstrated strong significant differences between the genotypes, environments and their interactions by all the estimated traits as well as differences in influence of these factors on formation of trait level (Table 2). Environment (E) was the dominant factor in productive tillering and grain weitht per plant variances $(50 \%$ and $49.7 \%$, respectively), but this factor is considered as of no importance upon genotype assessment, which allows focusing on the investigation of genotype $(\mathrm{G})$ and genotype $\times$ environment interaction $(\mathrm{GE})$ effects $[8,10]$.

Environmental variety trial results are always a large conglomeration of data, which are rather difficult to analyze without visualization. GGE biplot is an ideal tool to solve this problem, enabling discrimination of genotypes realizing their potentials in specific soil-climatic conditions or genotypes with wide adaptation to a variety of test environments.

In Fig. 1 the polygon vertices are genotype markers that are maximally remote from the biplot center, so all the genotype markers are inside the polygon. The lines dividing the biplot into sectors represent a set of hypothetical environments. The genotype forming the polygon angle for each sector dividing the biplot has the highest yield capacity in environments falling within this sector. 
Analysis of variance of quantitative trait levels in the spring barley varieties in the environmental trials, 2013.

\begin{tabular}{|c|c|c|c|c|}
\hline Variance & SS & $\mathrm{DF}$ & MS & $\% \mathrm{SS}^{*}$ \\
\hline \multicolumn{5}{|c|}{ Productive tillering } \\
\hline $\mathrm{E}$ & 19.47 & 2 & $9.74 * *$ & 50.9 \\
\hline $\mathrm{G}$ & 12.22 & 16 & $0.76^{* *}$ & 31.9 \\
\hline $\mathrm{E} \times \mathrm{G}$ & 3.92 & 32 & $0.12 * *$ & 10.2 \\
\hline Error & 2.66 & 51 & 0.05 & \\
\hline Total & 38.27 & 101 & & \\
\hline \multicolumn{5}{|c|}{ Grain number per spike } \\
\hline $\mathrm{E}$ & 89.04 & 2 & $44.52 * *$ & 16.5 \\
\hline $\mathrm{G}$ & 182.76 & 16 & $11.42 * *$ & 34.0 \\
\hline$E \times G$ & 216.41 & 32 & $6.76^{* *}$ & 40.2 \\
\hline Error & 49.72 & 51 & 0.97 & \\
\hline Total & 537.93 & 101 & & \\
\hline \multicolumn{5}{|c|}{ 1000-grain number } \\
\hline $\mathrm{E}$ & 160.62 & 2 & $80.3 * *$ & 14.1 \\
\hline $\mathrm{G}$ & 544.74 & 16 & $34.0 * *$ & 47.7 \\
\hline$E \times G$ & 381.62 & 32 & $11.9 * *$ & 33.4 \\
\hline Error & 54.01 & 51 & 1.1 & \\
\hline Total & 1140.95 & 101 & & \\
\hline \multicolumn{5}{|c|}{ Grain weight per plant (performance) } \\
\hline $\mathrm{E}$ & 16.09 & 2 & $8.04 * *$ & 49.7 \\
\hline $\mathrm{G}$ & 6.40 & 16 & $0.40 * *$ & 19.8 \\
\hline$E \times G$ & 9.49 & 32 & $0.30 * *$ & 29.3 \\
\hline Error & 0.41 & 51 & 0.01 & \\
\hline Total & 32.39 & 101 & & \\
\hline
\end{tabular}

$*-\%$ of the total variance of a trait; $* *$ - significant difference at significance level of $1 \%$.

Thus, the genotype of Kozvan variety (G12) had the maximum productive tillering in all the three environments, suggesting its wide adaptation by this trait. Modern variety (G14) was the winner by grain number per spike in environment E3, and Vitrazh (G6) - in environments E1 and E2. Vektor (G3) in environments E1 and E2 and Perl (G16) in environment E3 were noticeable for 100-grain weight. In environment E3 Agrariy (G1) variety had the highest performance, and in environments E1 and E2 Kozvan and Vitrazh varieties, which were similar by their parameters, showed the highest performance.

GGE biplot ranks genotypes by their performance and stability in a number of environments. In Fig. 2 the average tester coordinate (ATC) (X-axis) or the performance line passes through the biplot origin with an arrow indicating the positive end of the axis. The ATC Y-axis (stability axis) passes through the biplot origin and is perpendicular to the ATC X-axis. Thus, the mean value of a trait of a genotype is estimated by the projection of its marker to the ATC X-axis, and stability - by the projections to the ATC Y-axis.

Kozvan (G12), Kosar (G13), Alegro (G2), Vitrazh (G6), and Perl (G16) varieties were noticeable both for productive tillering and for grain weight per plant (correlation coefficient between these traits was significantly high, $r=0.85)$. Inklyuziv (G11), Vektor (G3), Vzirets (G4), Perl (G16), and Dyvoglyad (G7) varieties had the most stable productive tillering; Perl (G16), Inklyuzin (G11), Dyvoglyad (G7), Vzirets (G4), and Dokaz (G8) varieties had the most stable grain weight per plant, while Agrariy (G1), Kozvan (G12), and Etiket (G9) were characterized by the widest reaction norm to changes in cultivation conditions.

Among the studied varieties Kosar (G13) and Agrariy (G1) had the greatest grain number per spike; Kosar (G13), Vektor (G3), Etiket (G9), and Perl (G16) were the most stable.

Vektor (G3) and Perl (G16) varieties were distinguished for 1000-grain weight; Vektor (G3) and Parnas (G15) were the most stable. 


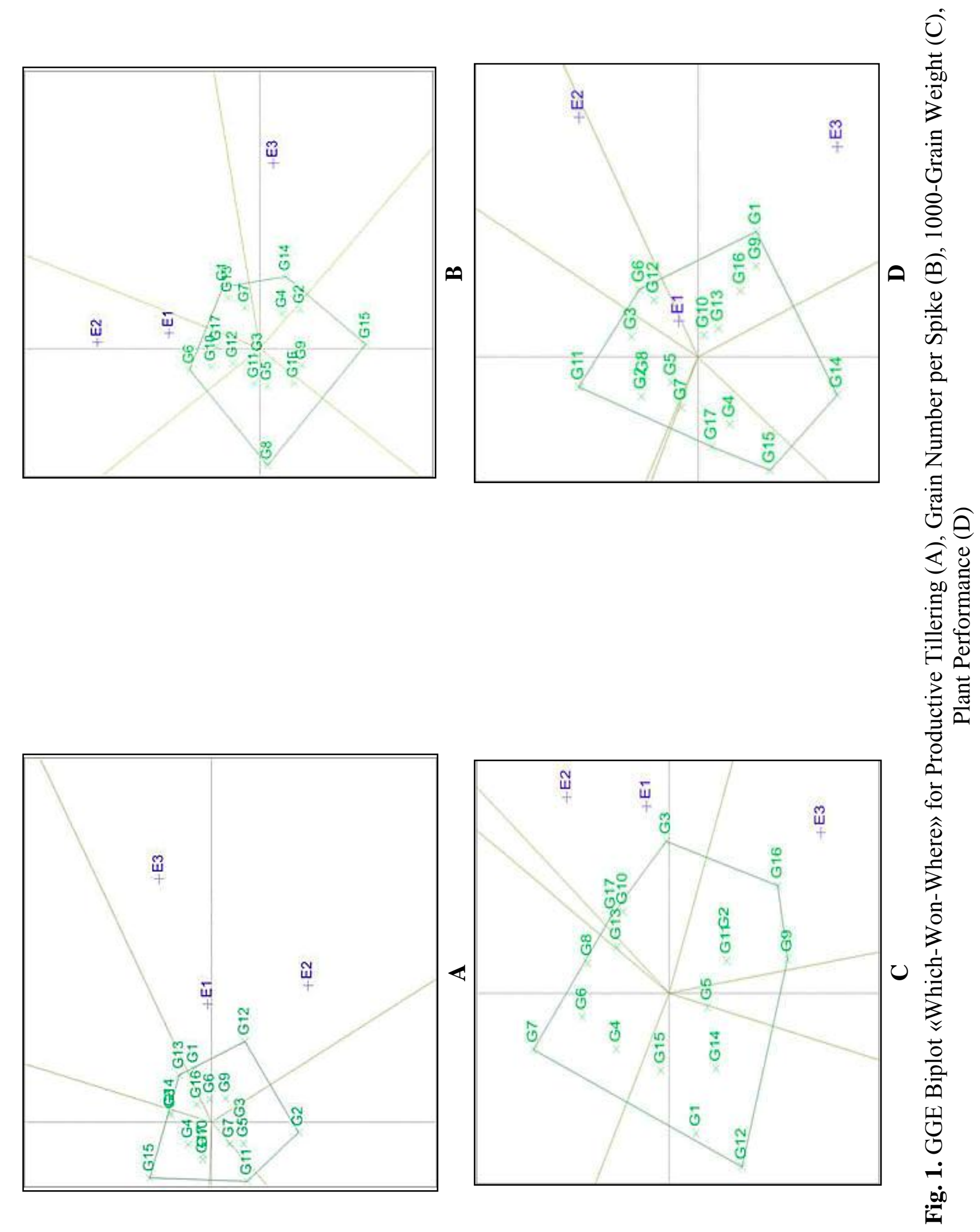



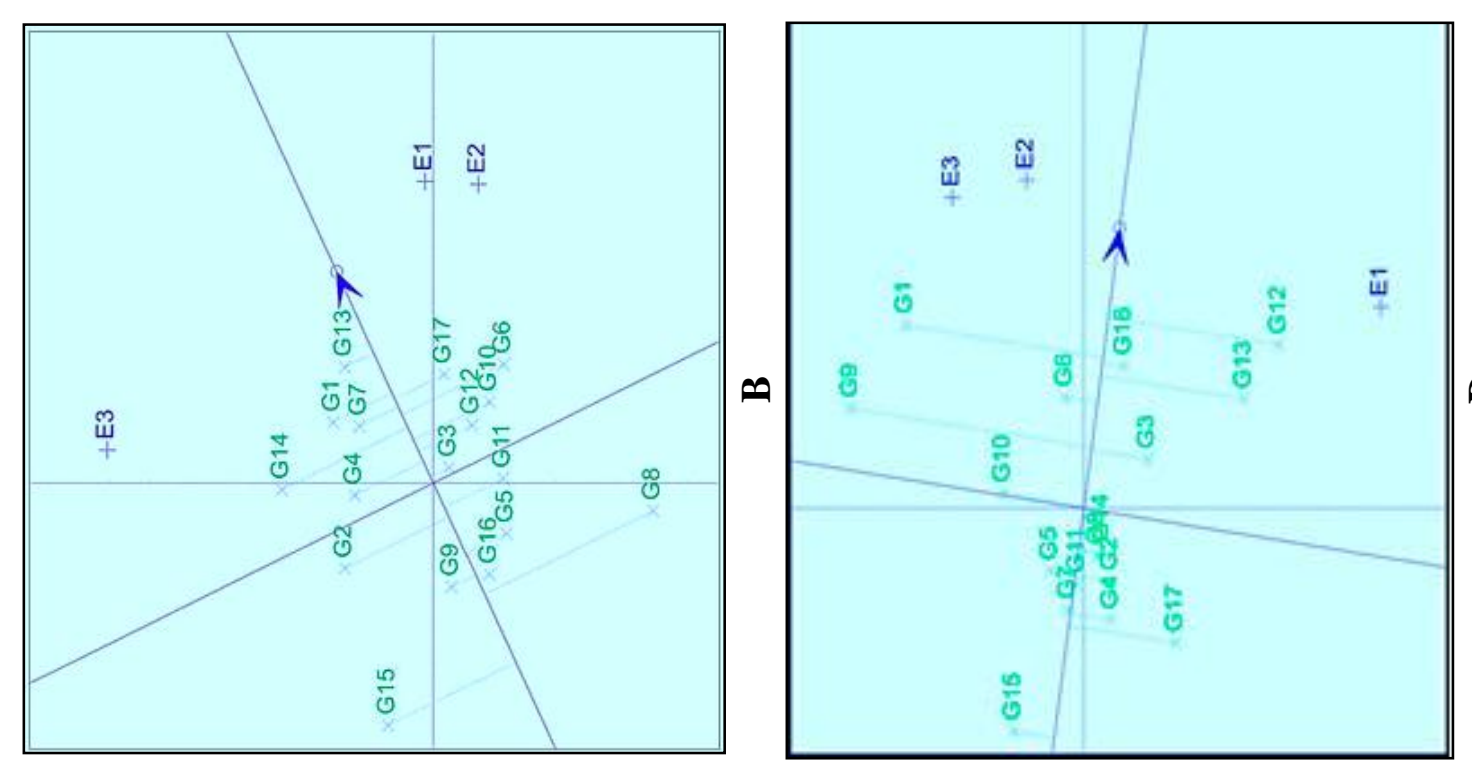

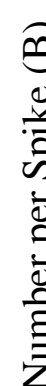

곡

ङ

อ

运

.

응

늘

पै สำ

记

䒕

完
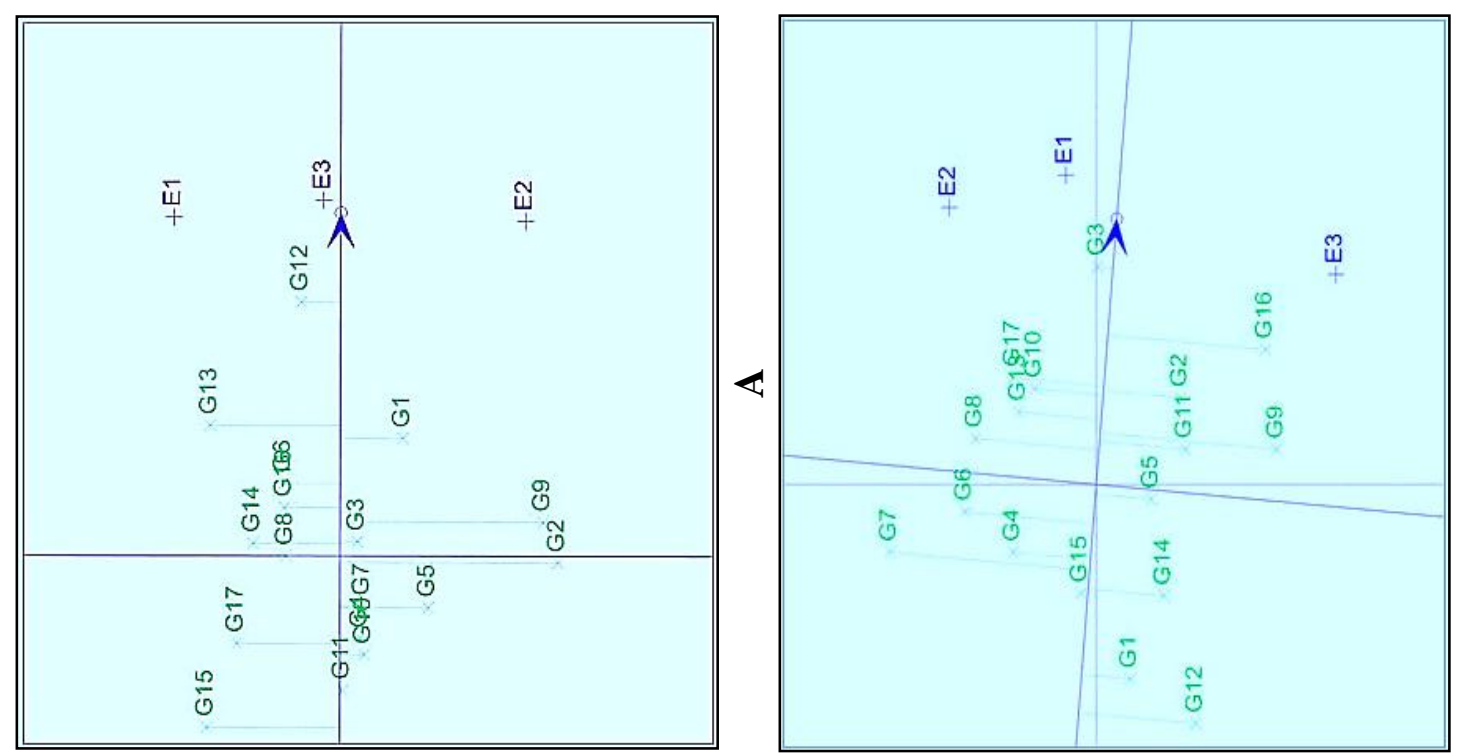

 

breeding.

Genotypes selected by level and stability of traits are valuable as source material for

In AV Kilchevskyy, LV Khotyleva and VV Khangildin methods there is a very important integral parameter "breeding value of genotype", which provides a comprehensive assessment of genotypes in terms of yield capacity and its stability. GGE biplot also ranks genotypes by "breeding value". The center of concentric circles (Fig. 3) represents the position of a genotype with maximum "breeding value" or so-called "ideal" genotype. The closer a genotype to the ideal one is, the more valuable it is. In our studies Kozvan (G12) variety was of the greatest breeding value in terms of productive tillering; Kosar (G13) variety - in terms of grain number; the awnless variety of Vektor (G3) - in terms of 1000-grain weight; Perl (G16) variety - in terms of performance, because it was much more stable than Kozvan variety, which exceeded Perl by performance (see Fig. 3).

The results of GGE biplot analysis of adaptive features of spring barley varieties very closely correlate with the results that we obtained by AV Kilchevskyy, LV Khotyleva method $[11,12]$, but GGE biplot has a number of advantages over the latter, in particular, it does not require heavy calculations.

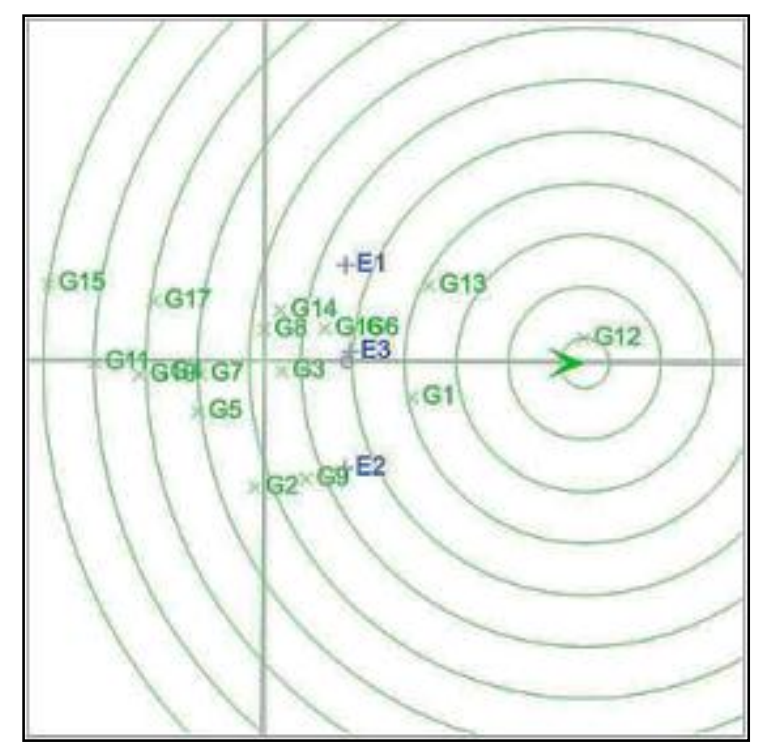

A

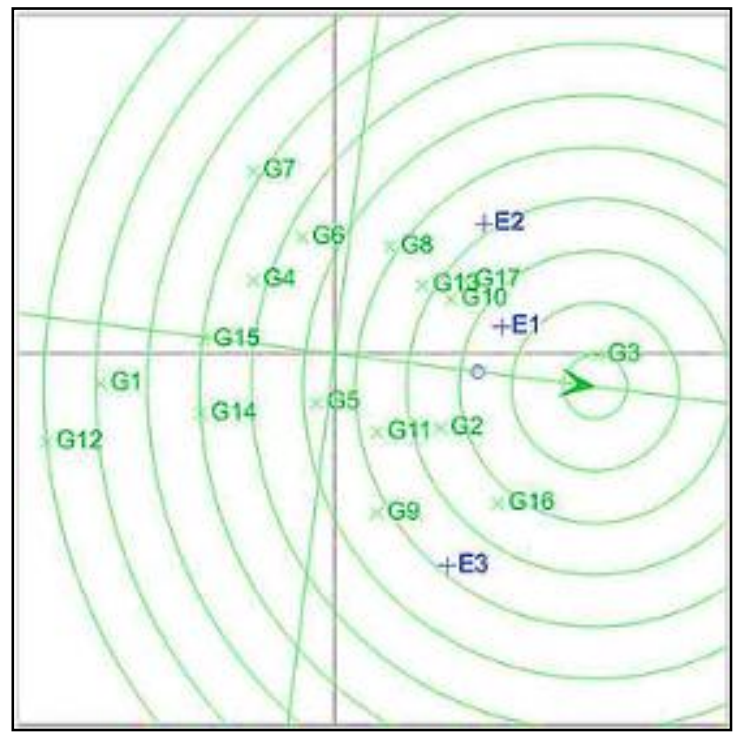

C

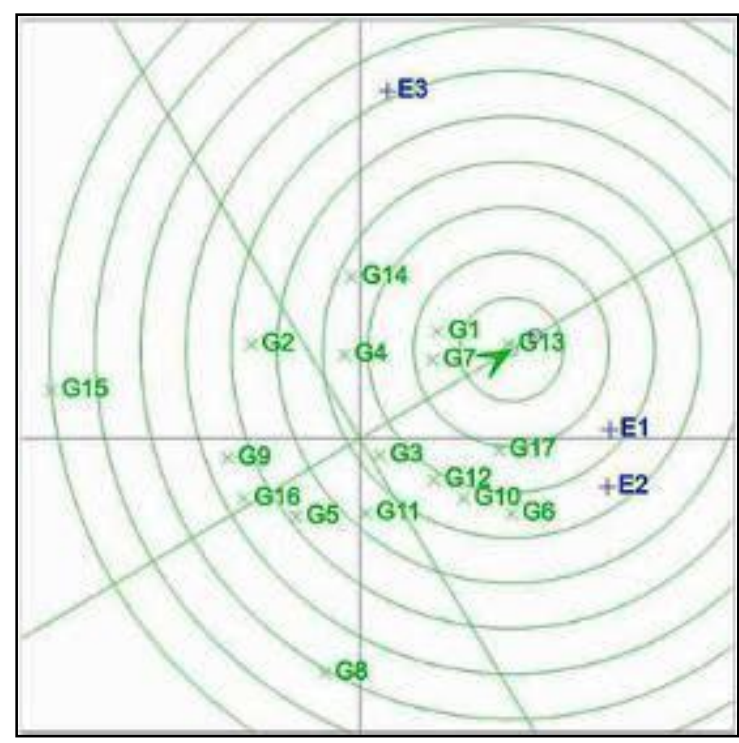

B

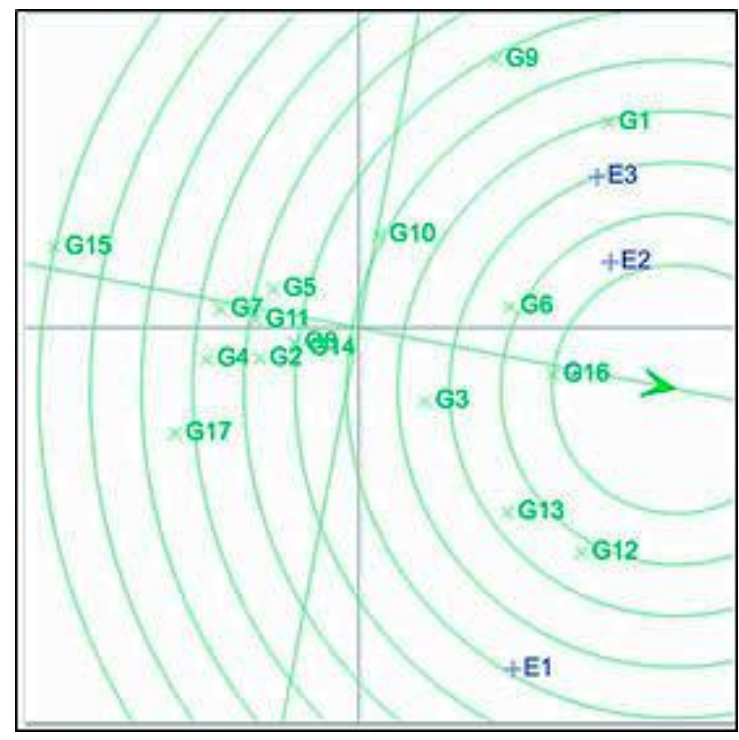

D

Fig. 3. GGE Biplot Based on Genotype-Centered Scaling for Comparison of Genotypes with the "Ideal" Genotype by Productive Tillering (A), Grain Number per Spike (B), 1000-Grain Weight (C), Plant Performance (D) 
Conclusions. Use of GGE biplot enabled analyzing the environmental trial data and discriminating the most valuable genotypes. Among the studied varieties of spring barley, Kozvan variety was the most valuable by productive tillering, Kosar variety - by grain number, Vektor variety - by 1000-grain weight, Perl and Kozvan varieties - by performance.

Thus, GGE biplot can be a comprehensive alternative to the most conventional methods of assessment of adaptive features in genotypes.

\section{Список використаних джерел}

1. Palanog, A. D. Adaptability and stability analysis of newly-released rice varieties using GGE biplot analysis [Text] / A. D. Palanog, C. A. Endino, I. M. G. Ciocon, L. T. Sta. Ines, E. M. Libetario. - Asia life sciences. - 2014. - 23 (2). - P. 515-526.

2. Rezene, Y. GGE and AMMI biplot analysis for field pea yield stability in SNNPR state, Ethiopia [Text] / Y. Rezene, A. Bekele, Y. Goa // International Journal of Sustainable Agricultural Research. - 2014. - 1 (1). - P. 28-38.

3. Yan, W. Biplot analysis of multi-environment trial data: Principles and applications [Text] / W Yan, N. A. Tinker // Can. J. Plant Sci. -2006. - 86. - P. 623-645.

4. Pourdad, S. S. Study on seed yield stability of sunflower inbred lines through GGE biplot [Text] / S. S. Pourdad, M. J. Moghaddam // Helia. - 2013. - 36. - Nr. 58. - P. 19-28.

5. GGE biplot vs. AMMI analysis of genotype - by- environment data [Text] / W. Yan, M. S. Kang, B. Ma, S. Woods, P. L. Cornelius // Crop Science. - 2007. - 47. - P. 643-655.

6. Cultivar evaluation and mega-environment investigation based on the GGE biplot [Text] / W. Yan, L. A. Hunt, Q. Sheny, Z. Szlavnics // Crop Science. - 2000. 40. - P. 597-605.

7. Yan, W. GGEbiplot - a Windows application for graphical analysis of multi-environment trial data and other types of twoway data/ W Yan - Agron. J. - 2001. - 93: - P. 1111-1118.

8. Yan, W. GGE biplot analysis: A graphical tool for breeders, geneticists and Agronomists [Text] / W. Yan, M. S. Kang. - CRC press, Boca Raton, FL. - 2003.

9. Yan, W. An integrated biplot analysis system for displaying, interpreting, and exploring genotype-byenvironment interactions [Text] / W Yan, Tinker, N. A. - Crop Sci. - 2005. - 45. - P. 1004-1016.

10. Fan, X. M. Yield stability of maize hybrids evaluated in multienvironment trials in Yunnan, China [Text] / X. M. Fan, M. S. Kang, H Chen,. Y. Zhang, J. Tan,, C. Xu. - Agron. J. - 2007. -99. - P. 220_228.

11. Солонечний, П. М. Стабільність елементів продуктивності сортів ячменю ярого в екологічному випробуванні [Текст] / П. М. Солонечний, М. Р. Козаченко, Н. І. Васько, О. Г. Наумов, П. П. Дмитренко, О. Л. Коваленко // Селекція і насінництво. - 2014. Вип. 105. - С. 194-203.

12. Солонечний, П. М. Оцінка адаптивної здатності та стабільності сортів ячменю ярого за продуктивністю [Текст] / П. М. Солонечний // Вісник ПДАА. - 2014. - № 4 (75). С. 48-53.

\section{References}

1. Palanog AD, Endino CA, Ciocon IMG, Sta. Ines LT, Libetario EM. Adaptability and stability analysis of newly-released rice varieties using GGE biplot analysis. Asia life sciences. 2014; 23(2):515-526.

2. Rezene Y, Bekele A, Goa Y. GGE and AMMI biplot analysis for field pea yield stability in SNNPR state, Ethiopia. International Journal of Sustainable Agricultural Research. 2014; 1 (1): 28-38.

3. Yan W, Tinker NA. Biplot analysis of multi-environment trial data: Principles and applications. Can. J. Plant Sci. 2006; 86:623-645.

4. Pourdad SS, Moghaddam MJ. Study on seed yield stability of sunflower inbred lines through GGE biplot. Helia. 2013; 36(58):19-28. 
5. Yan W, Kang MS, Ma B, Woods S, Cornelius PL. GGE biplot vs. AMMI analysis of genotype - by- environment data. Crop Sci. 2007; 47:643-655.

6. Yan W, Hunt L, A., Sheny Q, Szlavnics Z. Cultivar evaluation and mega-environment investigation based on the GGE biplot. Crop Sci. 2000; 40:597-605.

7. Yan W. GGEbiplot - a Windows application for graphical analysis of multi-environment trial data and other types of twoway data. Agron. J. 2001; 93: 1111-1118.

8. Yan W, Kang MS. GGE biplot analysis: A graphical tool for breeders, geneticists and Agronomists. CRC press : Boca Raton (FL). 2003.

9. Yan W, Tinker NA. An integrated biplot analysis system for displaying, interpreting, and exploring genotype-byenvironment interactions. Crop Sci. 2005; 45: 1004-1016.

10. Fan XM, Kang MS, Chen H, Zhang Y, Tan J, Xu C. Yield stability of maize hybrids evaluated in multi-environment trials in Yunnan, China. Agron. J. 2007; 99:220-228.

11. Solonechnyi PM, Kozachenko MR, Vasko NI, Naumov OG, Dmytrenko PP, Kovalenko OL. Stability of productivity elements in spring barley varieties under ecological testing conditions. Selektsia I nasinnitstvo. 2014; 105:194-203.

12. Solonechnyi PM. Adaptability and stability of spring barley cultivars in terms of performance. News Of The Poltava State Agrarian Academy. 2014; 4 (75):48-53.

\section{ОЦІНКА ФЕНОТИПОВОЇ СТАБІЛЬНОСТІ СОРТІВ ЯЧМЕНЮ ЯРОГО ЗА ДОПОМОГОЮ GGЕ ВIPLOT}

Солонечний П. М., Козаченко М. Р., Васько Н. І., Наумов О. Г., Солонечна О. В.,

Важеніна О. С.

Інститут рослинництва ім. В. Я. Юр'єва НААН, Україна

Бондарєва О. Б.

Донецька державна сільськогосподарська дослідна станція НААН, Україна

Коваленко О. Л.

Дослідна станція луб'яних культур ІСГПС НААН, Україна

Ячмінь є однією з основних сільськогосподарських культур в Україні, але збільшення валового виробництва зерна ячменю неможливе без впровадження високоврожайних, стійких до біотичних і абіотичних факторів сортів.

Мета і задачі дослідження. Метою досліджень була оцінка адаптивних особливостей сортів ячменю ярого за продуктивністю та іiі елементами за допомогою GGE biplot та виділення цінного вихідного матеріалу для селекції.

Матеріали і методи. В статті наведено GGE biplot аналіз даних екологічного випробування 17 сортів ячменю ярого селекції Інституту рослинництва ім. В. Я. Юр'єва НААН в трьох пунктах, що знаходяться в різних грунтово-кліматичних умовах. Було проведено оцінку мінливості елементів структури продуктивності рослини: маси зерна з рослини, продуктивної кущистості, кількості зерен з колоса та маси 1000 зерен.

Обговорення результатів. Дисперсійний аналіз підтвердив наявність високої достовірної різниці між генотипами, середовищами та їх взаємодією за всіма дослідженими ознаками, а також виявив неоднаковий вплив факторів на формування ознак. Максимальну продуктивну кущистість в усіх трьох середовищах мав сорт Козван, що свідчить про його широку адаптивність за цією ознакою. Сорт Модерн мав найбільшу кількість зерен в середовищі Е3, а сорт Вітраж в Е1 та Е2. За масою 1000 зерен виділилися сорти Вектор (E1 та E2) та Перл (Е3). В середовищі Е3 максимальну продуктивність мав сорт Аграpiй, а в E1 та Е2 близькі за своїми показниками сорти Козван та Вітраж. За продуктивною кущистістю та масою зерна з рослини виділено сорти Козван, Косар, Алегро, Вітраж та Перл. Найбільш стабільною продуктивна кущистість була у сортів Інклюзив, Вектор, Взірець, Перл та Дивогляд, маса зерна з рослини у сортів Перл, Інклюзив, Дивогляд , Взірець та Доказ. Найбільшу кількість зерен з колосу серед досліджених сортів мали сорти Косар та Аграрій, найбільш стабільними були Косар, Вектор, Етикет та Перл. За масою 1000 зерен виділено сорти Вектор та Перл, найбільш стабільними були Вектор та Парнас. 
Висновки. Серед досліджених сортів ячменю ярого виділено генотипи з високим рівнем ознаки та стабільним її проявом: за продуктивною кущистістю - Козван, за кількістю зерен з колоса - Косар, за масою 1000 зерен - Вектор, за масою зерна з рослини - сорти Перл та Козван. Ці сорти мають високу цінність для селекції в якості вихідного матеріалу. На думку авторів статті, GGE biplot може використовуватись як повноцінна альтернатива найбільш поширеним методикам оцінки адаптивних особливостей генотипів.

Ключові слова: GGE biplot, ячмінь ярий, екологічне випробування, стабільність, адаптивність, продуктивність, генотип

\section{ОЦЕНКА ФЕНОТИПИЧЕСКОЙ СТАБИЛЬНОСТИ СОРТОВ ЯЧМЕНЯ ЯРОВОГО С ПОМОЩЬЮ GGE ВIPLOT}

Солонечный П. Н., Козаченко М. Р., Васько Н. И., Наумов А. Г., Солонечная О. В., Важенина О. Е.

Институт растениеводства им. В. Я. Юрьева НААН, Украина

Бондарева О. Б.

Донецкая государственная сельскохозяйственная опытная станция НААН, Украина

Коваленко О. Л.

Опытная станция лубяных культур ИСХСВ НААН, Украина

Ячмень является одной из основных сельскохозяйственных культур в Украине, но увеличение валового производства зерна ячменя невозможно без внедрения высокоурожайных, устойчивых к биотическим и абиотическим факторам сортов этой культуры.

Цель и задачи исследования. Целью исследований была оценка адаптивных особенностей сортов ячменя ярового по продуктивности и ее элементам с помощью GGE biplot и выделение ценного исходного материала для селекции этой культуры.

Материалы и методы. В статье представлен GGE biplot анализ данных экологического испытания 17 сортов ячменя ярового селекции Института растениеводства им. В. Я. Юрьева НААН в трех пунктах, расположенных в разных почвенно-климатических условиях. Была проведена оценка изменчивости элементов структуры продуктивности растений: массы зерна с растения, продуктивной кустистости, количества зерен с колоса и массы 1000 зерен.

Обсуждение результатов. Дисперсионный анализ подтвердил наличие высокого достоверного различия между генотипами, средами и их взаимодействием по всем исследованным признакам, а также выявил неодинаковое влияние факторов на формирование признаков. Максимальная продуктивная кустистость во всех трех средах была у сорта Козван, что свидетельствует о его широкой адаптивности по этому признаку. Сорт Модерн имел наибольшее количество зерен в среде Е3 (Опытная станция лубяных культур), а сорт Витраж - в Е1 (Институт растениеводства им. В. Я. Юрьева) и Е2 (Донецкая опытная станция). По массе 1000 зерен выделились сорта Вектор (E1 та Е2) и Перл (Е3). В среде Е3 максимальная продуктивность была у сорта Аграрий, а в Е1 та Е2 близкими по своим показателям были сорта Козван и Витраж. По продуктивной кустистости и массе зерна с растения выделены сорта Козван, Косар, Алегро, Витраж и Перл. Наиболее стабильная продуктивная кустистость была у сортов Инклюзив, Вектор, Взирец, Перл та Дивогляд, масса зерна с растения - у сортов Перл, Инклюзив, Дивогляд , Взирец и Доказ. Наибольшее количество зерен в колосе среди исследуемых сортов имели сорта Косар и Аграрий, наиболее стабильными были Косар, Вектор, Этикет и Перл. По массе 1000 зерен выделены сорта Вектор и Перл, по стабильности - Вектор и Парнас.

Выводы. Среди исследуемых сортов ячменя ярового выделены генотипы с высоким уровнем признака и стабильным его проявлением: по продуктивной кустистости - Козван, по количеству зерен в колосе - Косар, по массе 1000 зерен - Вектор, Перл и Козван по продуктивности - Перл та Козван. Эти сорта представляют ценность для селекции в качестве исходного материала. По мнению авторов статьи, GGE biplot может служить 
полноценной альтернативой наиболее распространенным методикам оценки адаптивных особенностей генотипов.

\section{Ключевые слова: GGE biplot, ячмень яровой, экологическое испытание, стабильность, адаптивность, продуктивность, генотип}

\section{“GGE BIPLOT” ASSESSMENT OF PHENOTYPIC STABILITY OF SPRING BARLEY VARIETIES}

Solonechnyi P. M., Kozachenko M. R., Vasko N. I., Naumov O. G., Solonechna O. V., Vazhenina O. E.

Plant Production Institute nd. a V. Ya. Yuriev of NAAS, Ukraine

Bondareva O. B.

Donetsk Experiment Station of NAAS, Ukraine

Kovalenko A. L.

Research Station of Bast Crops of the Institute of Agriculture of Northern-East NAAS, Ukraine

Barley is among dominating agricultural plants in Ukraine, but increase in gross output of barley grain is impossible without implementation of high-yielding barley varieties that are resistant to biotic and abiotic factors.

The aim and tasks of the study. The study purpose was evaluation of adaptive features of spring barley varieties in terms of performance and its elements using GGE biplot and discrimination of valuable source material for breeding of this plant.

Materials and methods. The article presents GGE biplot analysis of results of environmental trials in 17 varieties of spring barley bred at the Plant Production Institute nd. a V. Ya. Yuriev of NAAS, which were conducted in three locations with different soil-climatic conditions. Variability of performance elements was evaluated: grain weight per plant, productive tillering, grain number per spike and 1000-grain weight.

Results and discussion. Analysis of variance confirmed strong significant differences between the genotypes, environments and their interactions by all the estimated traits as well as differences in influence of these factors on formation of traits. Kozvan variety had the maximum productive tillering in all the three environments, suggesting its wide adaptation by this trait. Modern variety had the greatest grain number in environment 3 (Research Station of Bast Crops), and Vitrazh variety - in environments E1 (Plant Production Institute nd. a V.Ya. Yuriev) and E 2 (Donetsk Experiment Station). Vektor in environments E1 and E2 and Perl in environment E3 were the winners in terms of 100-grain weight. In environment E3 Agrariy variety had the highest performance, and in environments E1 and E2 Kozvan and Vitrazh varieties, which were similar by their parameters, showed the highest performance. Kozvan, Kosar, Alegro, Vitrazh, and Perl varieties were noticeable for their productive tillering and grain weight per plant. Productive tillering was the most stable in Inklyuziv, Vzirets, Perl, and Dyvoglyad varieties; grain weight per plant was the most stable in Perl, Inklyuziv, Dyvoglyad, Vzirets and Dokaz. The greatest grain number per spike among the studied varieties was obtained in Kosar and Agrariy; Kosar, Vektor, Etiket, and Perl were the most stable. Vektor and Perl varieties were noticeable for 1000-grain weight; Vektor and Parnas were the most stable.

Conclusions. Among the studied varieties of spring barley, we discriminated varieties with high trait levels and its stable expression: Kozvan - by productive tillering, Kosar - by grain number per spike, Vektor, Perl and Kozvan - by 1000-grain weight, Perl and Kozvan - by performance. These varieties are valuable in breeding as source material. We think that GGE biplot can be a comprehensive alternative to the most conventional methods of assessment of adaptive features in genotypes.

Key words: GGE Biplot, spring barley, environmental variety trial, stabiltity, adaptability, performance, genotype 